\title{
EFFECTS OF PRETREATMENT, SOWING TIME, SOWING ENVIRONMIENT AND CLIMATE FACTORS ON GERMINATION IN ACER PSEUDOPLATANUS L.
}

\author{
UTJECAJ PREDSJETVENE PRIPREME, VREMENA \\ SJETVE, ZAŠTIĆENOG PROSTORA I KLIMATSKIH \\ ČIMBENIIKA NA KLIJAVOST SJEMENA VRSTE ACER \\ PSEUDOPLATANUS L.
}

\author{
Zafer YÜCESAN $^{1 *}$, Derya BAYRAM ${ }^{1}$
}

\begin{abstract}
SUMIMARY
In this study, the effects of different sowing environment (greenhouse and nursery), pretreatment (cold moist stratification), different sowing time (autumn, spring and summer) and some climate factors (air temperature, relative air humidity, soil temperature and soil moisture) on the germination of Acer pseudoplatanus L. seeds were studied. Seeds were harvested from the tree located in the Karadeniz Technical University campus. Three different germination trials were carried out; (1) direct sowing in autumn after seed collection (Control), (2) sowing stratified seeds in spring (Stratification-1) and (3) sowing stratified seeds in summer (Stratification-2). During the germination trial processes, air temperature, relative air humidity, soil temperature and soil moisture were measured periodicaly. Thus, the germination percentage changes in different sowing environments have been established on the basis of some climate factors. Higher germination percentages were obtained in the autumn (Control) compared to the spring (Stratification-1) and summer (Stratification-2) sowings. The highest percentages of germination were determined in the control trials (70\% in greenhouse and $58 \%$ in nursery). Obtained germination results based on different sowing times revealed secondary dormancy in Acer pseudoplatanus L. seeds. It has been determined that the mean germination time in the greenhouse (12 days) was shorter than the mean germination time in the nursery (18 days). In addition, the obtained results showed that stratification and sowing time have a positive effect on the mean germination time in the greenhouse. Because of getting the best germination rates, keeping some climate factors constant $\left(21.0-24.9^{\circ} \mathrm{C}\right.$ air temperature; $17.0-19.9^{\circ} \mathrm{C}$ soil temperature; $63.0-68.9 \%$ relative air humidity; $60.0-67.9 \%$ soil moisture) during the vegetative propagation practices in the greenhouse, should affect mass seedling production in Acer pseudoplatanus L.
\end{abstract}

KEY WORDS: Cold-moist stratification; sowing time; seed storage; greenhouse; nursery

\footnotetext{
${ }^{1}$ Assoc. Prof. Dr. Zafer Yücesan, Derya Bayram, forest engneer, Karadeniz Technical University Faculty of Forestry Forest Engineering Department ${ }^{*}$ Corresponding author: Assoc. Prof. Dr. Zafer YÜCESAN

Address: Karadeniz Technical University, Faculty of Forestry, Forest Engineering Department, 61080, Ortahisar/Trabzon/Turkey. e-mail: yucesan@ktu.edu.tr

Telephone: +90 4623773527

Fax: +90 4623257499
} 


\section{INTRODUCTION} UVOD

Sycamore maple (Acer pseudoplatanus L.) produces economically attractive timber, offers ecological services and has high land compatibility, but is only a small component of European forests (Vacek et al. 2018). Despite its potential economic and ecological significance (Spiecker et al. 2009), the share of the sycamore maple generally does not exceed 3\% by most national inventories in Europe (Hein 2009). This low stand volume is due to the fact that the sycamore maple tree rarely forms pure forest stands (Jones 1945; Hein et al. 2009). In Turkey, it spreads around 1000 meters in the Black Sea coastal forests of Thrace (Gültekin 2007). Yaltırik (1971) stated that this species does not have a natural distribution area in Turkey, but it comes artificially.

As a result of the rapid increase of the world population and the expansion of the global economy, the pressure on natural resources is increasing day by day. As in many countries, a large part of the forests in Turkey have been damaged due to various reasons (climate change, fragmentation, social pressure and etc.) and forests could not provide the required benefits in terms of both quantity and quality. Moreover, since the decrease in forest areas as a result of rapid population growth will increase the need for wood raw material in the future, more forest areas and therefore planned afforestation works are needed for supplying increasing wood raw material demand and to prevent air, land and water pollution caused by industrialization (Ürgenç 1998).

Afforestation works are mostly established for various purposes such as water and soil protection, wood production and carbon sequestration The effects of recent afforestation activities on biological diversity are also discussed. It is stated that the priority in afforestation studies is the need to protect the natural plant taxa in the area (Bremer and Farley 2010). Many researchers stated that sycamore increases biodiversity and ecological stability of forest ecosystems (Binggeli 1993; Pommerening 1997; Bell 2009) and it is soil-improving tree species that increased humus formation and nutrient cycling (Weber et al. 1993; Heitz and Rehfuess 1999). So, it is possible to say sycamore has an important potential to respond to projected future climate change (Kölling 2007; Hein et al. 2009). On account of, the species has value for both the forest sector and the wood processing industry especially in Central Europe (Spiecker et al. 2009; Thies et al. 2009; Vacek et al. 2018).

Maple seeds, which are in the category of orthodox and recalcitrant seeds during germination, may differ from species to species (Gültekin 2007). Seeds of maple species are considered by most researchers as seeds with germination barriers (Bradbeer 1988; Derkx 2000; Piotto et al. 2001; Gleiser et al. 2004; Zasada and Strong 2008). Although pericarp, seed coat and embryo dormancy are seen in maples, there are differences between species in terms of morphological and physiological dormancy (Young and Young 1992). Depending on the dormancy types, there are different techniques for romoving dormancy in Acer ssp. seeds. Cold-moist stratification is the widely used method for removing dormancy in many Acer species (Farmer and Cunningham 1981; Tylkowski 1995; Tremblay et al. 1996; Savage et al. 1998; Bourgoin and Simpson 2004; Gültekin 2007; Farhadi et al. 2013; Erdoğan Genç and Üçler 2020a; Erdoğan Genç and Üçler 2020b). In addition, gibberellic acid also promotes removing seed dormancy and stimulates seed germination in many species (Chen and Chang 1972; Beyhan et al. 1999; Phartyal et al. 2003a; Drăghici and Abrudan 2010; Stejskalová et al. 2015; Kumar et al. 2017).

Seeds usually respond to a combination of different environmental factors such as light, temperature and soil moisture that best suit their structure (Baskin and Baskin 1998). Germination occurs at a certain thermal rate, so temperature is the determining factor for germination and is directly related to the ecological characteristics of the species (De Castro and Hilhorst 2004). For most species, the prevailing soil temperature determines both the growth and germination rate of the seeds (Heydecker 1977).

Main goals of the study are (1) to investigate the effects of cold-moist stratification, sowing time and sowing environment (greenhouse and nursery) on the germination ability of the sycamore maple seeds, (2) to determine the best suitable climate factors for better germination ability and (3) to create basis knowledge for the further studies in terms of mass seedling production.

\section{MATERIAL AND METHODS MATERIJALI I METODE}

\section{Seed material - Sjemenski materijal}

Seeds harvested from a single sycamore maple tree which is located in the Kanuni campus of Karadeniz Technical University $\left(40^{\circ} 59^{\prime} 47^{\prime \prime} \mathrm{N} ; 39^{\circ} 46^{\prime} 20^{\prime \prime} \mathrm{E}\right)$ were used as material. Altitude of the location of the single seed family above sea level is approximately 100 meters and the exposure is north. The seeds were harvested in September 2017.

Seeds were collected by hand from the middle-inner part of the crown of the seed family. Collected seeds were cleared from branches, leaves and stems in laboratory. After cleaning and the visually injured or damaged ones of the seeds were removed, the extracted seeds without wings were airdried (10\% seed moisture content). The flotation method was applied by using $96 \%$ ethanol in order to separate healthy seeds. 400 (4x100) seeds were used to determine the fullness rate. By using $800(8 \times 100)$ seeds, the mean 1000 Kernel Weights (g) of the seeds were determined according to ISTA (1996). Mean 1000 Kernel Weights (g) of the harvested seeds 
Table 1. Important hydrological properties of the soil in the greenhouse and nursery

Tablica 1. Važna hidrološka svojstva tla u stakleniku i rasadniku

\begin{tabular}{|c|c|c|c|c|c|c|}
\hline $\begin{array}{l}\text { Sowing } \\
\text { Environment } \\
\text { Sjetveni } \\
\text { Okoliš }\end{array}$ & $\begin{array}{l}\text { Hygroscopic } \\
\text { moisture } \\
\text { Higroskopna } \\
\text { vlaga } \\
(\%)\end{array}$ & $\begin{array}{c}\text { Wilting point } \\
\text { Točka venuća } \\
(\%)\end{array}$ & $\begin{array}{c}\text { Field capacity } \\
\text { Poljski kapacitet } \\
\text { (\%) }\end{array}$ & $\begin{array}{c}\text { Saturation } \\
\text { Saturacija } \\
(\%)\end{array}$ & $\begin{array}{l}\text { Available water } \\
\text { holding capacity } \\
\text { Dostupni kapacitet } \\
\text { zadržavanja vode } \\
\text { (mm/cm) }\end{array}$ & $\begin{array}{c}\text { Hydraulic } \\
\text { conductivity } \\
\text { Hidraulička } \\
\text { provodlfivost } \\
\text { (cm/s) }\end{array}$ \\
\hline $\begin{array}{l}\text { Nursery } \\
\text { Rasadnik }\end{array}$ & 4,70 & 12,50 & 23,80 & 59,20 & 1,10 & 10,16 \\
\hline $\begin{array}{l}\text { Greenhouse } \\
\text { Staklenik }\end{array}$ & 5,40 & 19,50 & 31,90 & 53,30 & 1,20 & 2,31 \\
\hline
\end{tabular}

Table 2. Important physical and chemical properties of the soil in the greenhouse and nursery

Tablica 2. Važna fizikalna i kemijska svojstva tla u stakleniku i rasadniku

\begin{tabular}{|c|c|c|c|c|c|c|}
\hline $\begin{array}{l}\text { Sowing } \\
\text { Environment } \\
\text { Sjetveni Okoliš }\end{array}$ & $\begin{array}{l}\text { Bulk density } \\
\text { Nasipna gustoća } \\
\left(\mathrm{gr} / \mathrm{cm}^{3}\right)\end{array}$ & $\begin{array}{l}\text { Sand } \\
\text { Pijesak } \\
(\%)\end{array}$ & $\begin{array}{c}\text { Clay } \\
\text { Glina } \\
(\%)\end{array}$ & $\begin{array}{l}\text { Silt } \\
\text { Mulj } \\
(\%)\end{array}$ & pH & $\begin{array}{c}\text { Organic matter } \\
\text { Organska tvar } \\
(\%)\end{array}$ \\
\hline $\begin{array}{l}\text { Nursery } \\
\text { Rasadnik }\end{array}$ & 1,08 & 72,63 & 10,58 & 16,79 & 5,26 & 6,71 \\
\hline $\begin{array}{l}\text { Greenhouse } \\
\text { Staklenik }\end{array}$ & 1,24 & 58,69 & 26,51 & 14,80 & 4,84 & 5,37 \\
\hline
\end{tabular}

was $184 \mathrm{~g}$, and the fullness rate was $67 \%$. Some important hydrological, physical and chemical properties of the soil used in seedbeds were shown in Table 1 and in Table 2.

\section{Germination trials - Pokusna ispitivanja klijavosti}

In this study, 3 different germination trials were tested. (1) First germination trial was the direct sowing after seed collection without any pretreatment (Control) which was constructed in November 2017 in the greenhouse and in the nursery. (2) Second germination trial (Stratification-1) was sowing seeds in spring after cold-moist stratification. Seeds were mixed with humidified sand with $40 \%$ moisture content in plastic bags and placed in a cooler at $+4{ }^{\circ} \mathrm{C}$ for coldmoist stratification. Stratification should be continued until the first germinant appear in stratification medium (Piotto et al. 2001; Zasada and Strong 2008). After 90 days of cold-moist stratification, first germinant appeared in the stratification medium and ungerminated seeds were taken from the stratification medium and sown on seedbeds in the greenhouse and in the nursery in March 2018 (Stratification-1). (3) Third germination trial (Stratification-2) was sowing stored seeds in summer after cold moist stratification. Until the Stratification-2 trial started, some of the harvested seeds were placed in polyethylene bags with $10 \pm 2 \%$ moisture content and were stored in a cooler at $+4{ }^{\circ} \mathrm{C}$ for five months. Stratification-2 was started in March 2018; stored seeds were mixed with humidified sand with $40 \%$ moisture content in plastic bags and placed in a cooler at $+4{ }^{\circ} \mathrm{C}$. Third sowing was done in June 2018 after 90 days of cold-moist stratification in the greenhouse and in the nursery. Both sowings were carried out by using the line sowing method. Since the seedbed area was narrower than the nursery, line sowing method was applied with 5x30 sampling in the nursery and 6x25 sampling in the greenhouse.

During each germination trial process soil moisture, soil temperature, relative air humidity and air temperature values were measured and recorded on two days in the greenhouse and in the nursery to reveal the climate factors that affected germination. Grouped data was performed for soil temperature, air temperature, relative air humidity and soil moisture values and the intervals that the best germination percentages obtained were determined. Weed control was done regularly on the seedbeds and irrigation was carried out at regular intervals.

\section{Determination of germination percentage and mean germination time - Određivanje postotka klijavosti $i$ prosječnog vremena klijavosti}

The germination percentage (GP) was calculated by the equation (1):

$$
G P=\left(\left(\sum x i\right) \div N\right) \times 100
$$

Where is the mumber of germinated seeds on day $i, N$ is the total number of tested seeds.

Mean germination time (MGT) was calculated by the equation (2):

$$
M G T=\frac{\left(\sum n i\right) \times\left(\sum t i\right)}{T}
$$

Where $n i$ is the number of the days, $t i$ is the number of germinated seeds in a given number of days, $T$ is the total number of germinated seeds. 


\section{Statistical Analysis - Statistička analiza}

One Way ANOVA test was used to determine whether the germination results were significantly different or not on the basis of different sowing environments, pretreatments, air temperature, soil temperature, relative air humidity and soil moisture. SPSS 20.0 statistical software was used to evaluate the obtained data.

\section{RESULTS}

\section{REZULTATI}

\section{Germination percentages - Postotak klijavosti}

While the highest germination percentage (70\%) in the greenhouse environment was obtained as a result of the control trial, the lowest germination percentage (24\%) was obtained from the stratification- 2 trial. Moreover, the highest germination percentage (58.1\%) in the nursery was also obtained as a result of the control trial and the lowest germination percentage (10.5\%) was obtained as a result of the stratification-2 trial. In the stratification- 1 trial, the average germination percentage of $44 \%$ was obtained both in the greenhouse and in the nursery.

\section{Air temperature and germination percentage - Temperatura zraka i postotak klijavosti}

The highest germination percentages in the greenhouse were obtained as $54.7 \%$ at the $21.0-24.9^{\circ} \mathrm{C}$ air temperature level in the control trial, as $30 \%$ at the same air temperature level in the stratification- 1 trial and as $15 \%$ at the $25.0-28.9$ ${ }^{\circ} \mathrm{C}$ air temperature level in the stratification-2 trial. The highest germination percentages in the nursery were obtained as $22 \%$ at the $13.0-16.9^{\circ} \mathrm{C}$ air temperature level in the control trial, as $20.5 \%$ at the $17.0-20.9^{\circ} \mathrm{C}$ air temperature level in the stratification- 1 trial and as $8 \%$ at the 25.0 $28.9^{\circ} \mathrm{C}$ air temperature level in the stratification-2 trial.

No germination was observed after $29.0-32.9^{\circ} \mathrm{C}$ air temperature level in the greenhouse. On the other hand, germination was observed at the $37.0-40.9^{\circ} \mathrm{C}$ air temperature level in the nursey. In the control and in the stratification 1 trials, germination was started at lower air temperature levels in the nursery $\left(9.0-12.9^{\circ} \mathrm{C}\right.$ and $13.0-16.9^{\circ} \mathrm{C}$ respectively) than the greenhouse $\left(17 \cdot 0-20 \cdot 9^{\circ} \mathrm{C}\right)$. However, in the stratification 2 trial, germination was observed at the $25.0-28.9^{\circ} \mathrm{C}$ air temperature levels both in the nursery and in the greenhouse (Figure 1).

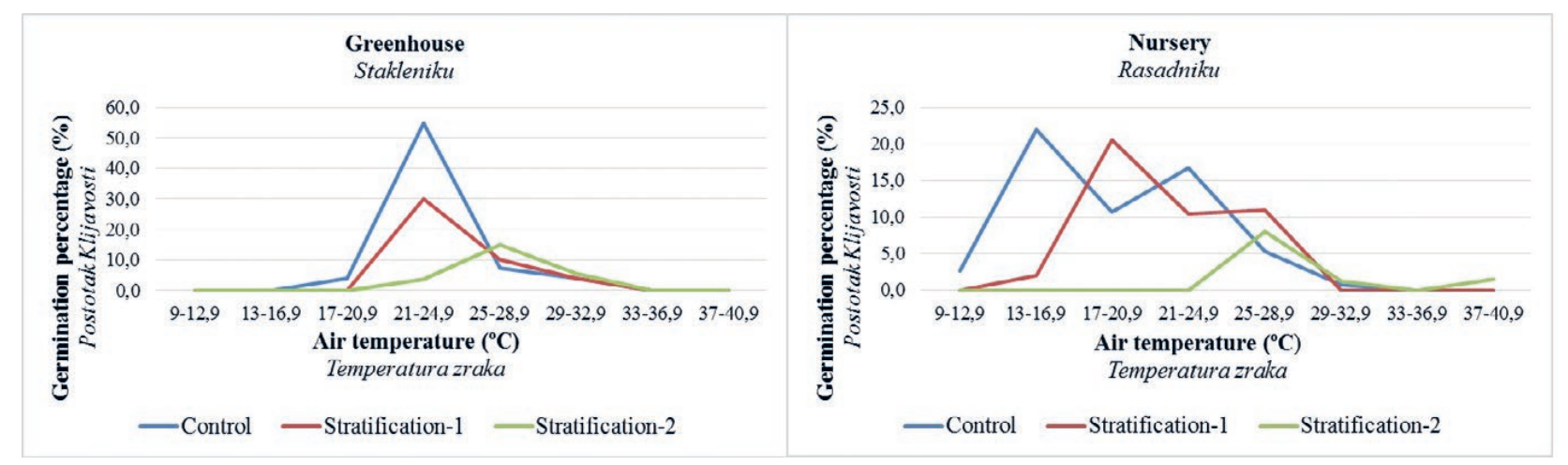

Figure 1. Germination percentages based on air temperature levels

Slika 1. Postoci klijanja s obzirom na temperaturu zraka

Table 3. Results of ANOVA on the basis of air temperature

Tablica 3. Rezultati ANOVA za temperaturu zraka

$\begin{array}{lccccc}\begin{array}{l}\text { Variable Source } \\ \text { Izvor varijabilnosti }\end{array} & \begin{array}{c}\text { Sum of squares } \\ \text { Suma kvadrata }\end{array} & \begin{array}{c}\text { Degree of freedom } \\ \text { Stupnjevi slobode }\end{array} & \begin{array}{c}\text { Mean square } \\ \text { Srednji kvadrat }\end{array} & \begin{array}{c}\text { F-value } \\ \text { F-vrijednost }\end{array} & \begin{array}{c}\text { p-value } \\ \text { p-vrijednost }\end{array} \\ \begin{array}{l}\text { Sowing environment } \\ \text { Sjetveni Okoliš }\end{array} & 13,441 & 1 & 13,441 & 0,374 & 0,549 \\ \begin{array}{l}\text { Pretreatment } \\ \text { Predtretmani }\end{array} & 275,650 & 2 & 137,825 & 3,834 & 0,044 \\ \begin{array}{l}\text { Air temperature level } \\ \text { Temperature zraka }\end{array} & 1787,716 & 7 & 255,388 & 7,104 & 0,001 \\ \begin{array}{l}\text { Sowing environment }{ }^{*} \text { Air temperature level } \\ \text { Sjetveni Okolis* } \text { Temperature zraka }\end{array} & 861,496 & 7 & 123,071 & 3,423 & 0,020 \\ \begin{array}{l}\text { Pretreatment* } \text { Air temperature level } \\ \text { Predtretmani* Temperature zraka }\end{array} & 1175,013 & 14 & 83,929 & 2,335 & 0,050\end{array}$


ANOVA test results showed significant differences $(p<0.05)$ between germination percentages according to the pretreatment, air temperature level, sowing environment ${ }^{*}$ air temperature level and pre-treatment ${ }^{*}$ air temperature level interactions. On the other hand, there were no significant differences between the greenhouse and nursery germination percentages (Table 3 ).

\section{Soil temperature and germination percentage - Temperatura tla i postotak klijavosti}

The highest germination percentages in the greenhouse were obtained as $43.3 \%$ at the $17.0-19.9^{\circ} \mathrm{C}$ soil temperature level in the control trial, as $17.5 \%$ at the $20.0-22.9^{\circ} \mathrm{C}$ soil temperature level in the stratification- 1 trial, as $12.5 \%$ at the 23.0-25.9 ${ }^{\circ} \mathrm{C}$ soil temperature level in the stratification-2 trial. The highest germination percentages in the nursery were obtained as $20 \%$ at the $8.0-10.9^{\circ} \mathrm{C}$ soil temperature level in the control trial, as $15 \%$ at the $14.0-16.9^{\circ} \mathrm{C}$ soil temperature level in the stratification- 1 trial and as $7 \%$ at the 26.0-28.9 ${ }^{\circ} \mathrm{C}$ soil temperature level in the stratification-2 trial. No germination was observed in the greenhouse while the soil temperature reached to the $14.0-16.9^{\circ} \mathrm{Clevel}$ and after the soil temperature level of $26.0-28,9^{\circ} \mathrm{C}$. However, germinations were observed in the nursery after the 29.0$31.9^{\circ} \mathrm{C}$ soil temperature level in the stratification- 2 trial. No germination was observed in the nursery while the soil temperature reached to the $23.0-25.9^{\circ} \mathrm{Clevel}$ in the stratification-2 trial, but germinations were observed in the nursery at the $8.0-10.9^{\circ} \mathrm{C}$ soil temperature level in the control and in the stratification- 1 trials (Figure 2).

ANOVA Test results showed significant differences $(p<0.05)$ between germination percentages according to the pretreatment and the soil temperature level. On the other hand, there were no significant differences between greenhouse and nursery germination percentages. Moreover no significant differences were found according to the sowing environment ${ }^{*}$ soil temperature level and the pretreatment ${ }^{\star}$ soil temperature level interactions (Table 4).

\section{Relative air humidity and germination percentage - Relativna vlažnost zraka i postotak klijavosti}

The highest germination percentages in the greenhouse were obtained as $33.3 \%$ at the $63.0-68.9$ relative air humudity level in the control trial, as $21.5 \%$ at the $75.0-80.9 \%$ relative air humudity level in the stratification-1 trial and as $17.5 \%$ at the $81.0-86.9 \%$ relative air humidity level in the

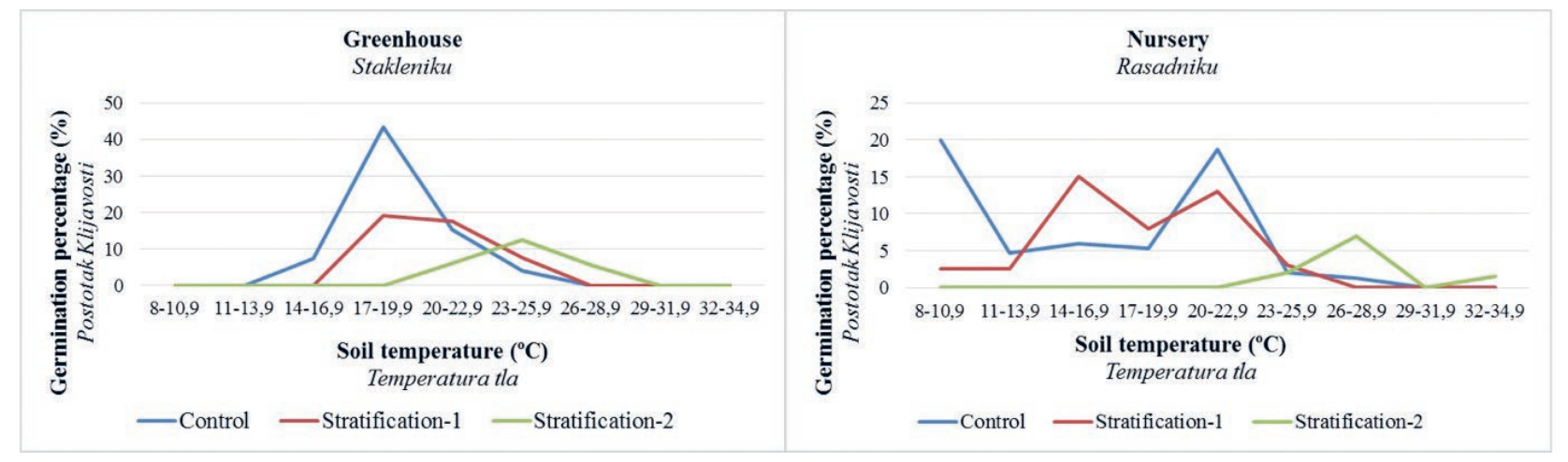

Figure 2. Germination percentages based on soil temperature levels Slika 2. Postoci klijanja s obzirom na temperaturu tla

Table 4. Results of ANOVA on the basis of soil temperature Tablica 4. Rezultati ANOVA za temperature tla

$\begin{array}{lccccc}\begin{array}{l}\text { Variable Source } \\ \text { Izvor varijabilnosti }\end{array} & \begin{array}{c}\text { Sum of squares } \\ \text { Suma kvadrata }\end{array} & \begin{array}{c}\text { Degree of freedom } \\ \text { Stupnjevi slobode }\end{array} & \begin{array}{c}\text { Mean square } \\ \text { Srednji kvadrat }\end{array} & \begin{array}{c}\text { F-value } \\ \text { F-vrijednost }\end{array} & \begin{array}{c}\text { p-value } \\ \text { p-vrijednost }\end{array} \\ \begin{array}{l}\text { Sowing environment } \\ \text { Sjetveni Okoliš }\end{array} & 11,947 & 1 & 11,947 & 0,339 & 0,568 \\ \begin{array}{l}\text { Pretreatment } \\ \text { Predtretmani }\end{array} & 244,034 & 2 & 122,017 & 3,461 & 0,050 \\ \begin{array}{l}\text { Soil temperature level } \\ \text { Temperature tla }\end{array} & 1038,599 & 8 & 129,825 & 3,682 & 0,010 \\ \begin{array}{l}\text { Sowing environment * Soil temperature level } \\ \text { Sjetveni Okoliš * Temperature tla }\end{array} & 570,766 & 8 & 71,346 & 2,023 & 0,102 \\ \begin{array}{l}\text { Pretreatment * Soil temperature level } \\ \text { Predtretmani * Temperature tla }\end{array} & 0,443 & 16 & 52,465 & 1,488 & 0,207\end{array}$


Table 5. Results of ANOVA on the basis of relative air humidity

Tablica 5. Rezultati ANOVA za relativnu vlažnost zraka

\begin{tabular}{|c|c|c|c|c|c|}
\hline $\begin{array}{l}\text { Variable Source } \\
\text { Izvor varijabilnosti }\end{array}$ & $\begin{array}{l}\text { Sum of squares } \\
\text { Suma kvadrata }\end{array}$ & $\begin{array}{l}\text { Degree of freedom } \\
\text { Stupnjevi slobode }\end{array}$ & $\begin{array}{l}\text { Mean square } \\
\text { Srednji kvadrat }\end{array}$ & $\begin{array}{c}\text { F - value } \\
\text { F-vrijednost }\end{array}$ & $\begin{array}{c}p \text {-value } \\
p \text {-vrijednost }\end{array}$ \\
\hline $\begin{array}{l}\text { Sowing environment } \\
\text { Sjetveni Okoliš }\end{array}$ & 10,837 & 1 & 10,837 &, 357 & 0,557 \\
\hline $\begin{array}{l}\text { Pretreatment } \\
\text { Predtretmani }\end{array}$ & 220,075 & 2 & 110,038 & 3,628 & 0,045 \\
\hline $\begin{array}{l}\text { Relative air humidity level } \\
\text { Relativnu vlažnost zraka }\end{array}$ & 496,848 & 9 & 55,205 & 1,820 & 0,127 \\
\hline $\begin{array}{l}\text { Sowing environment }{ }^{*} \text { Relative air humidity level } \\
\text { Sjetveni Okoliš * Relativnu vlažnost zraka }\end{array}$ & 238,021 & 9 & 26,447 & 872 & 0,565 \\
\hline $\begin{array}{l}\text { Pretreatment }{ }^{*} \text { Relative air humidity level } \\
\text { Predtretmani }{ }^{*} \text { Relativnu vlažnost zraka }\end{array}$ & 981,445 & 18 & 54,525 & 1,798 & 0,103 \\
\hline
\end{tabular}

stratification-2 trial. In the nursery, the highest germination percentages were obtained as $23 \%$ at the $57.0-62.9 \%$ relative air humudity level in the stratification-1 trial, as $20 \%$ at the $63.0-68.9 \%$ relative air humidity level in the control trial and as $8.5 \%$ at the $75.0-80.9 \%$ relative air humudity level in the stratification-2 trial.

While no germinations were observed after the 87.0-92.9\% air humidity level in the control and in stratification-2 trials in the greenhouse, germinations were observed after the relative air humidity level of $87.0-92.9 \%$ in the stratification-1 trial. In the stratification- 2 trial, no germination was observed up to the $69.0-74.9 \%$ relative air humidity level both in the greenhouse and in the nursery, but germinations were observed in the greenhouse at the 39.0-44.9\% relative air humidty level in the control trial and at the 51.0$56.9 \%$ relative air humidty level in the stratification 1 trial. No germination was observed in the nursery up to the 45.0$50.9 \%$ relative air humidity level in the control and in the stratification-1 trial. Moreover, no germination was observed in the nursery after the $81.0-86.9 \%$ relative air humidty level in the stratification- 1 trial. However, germinations were observed in the nursery after the 81.0-86.9\% relative air humidty level in the control and in the stratification-2 trials (Figure 3).
ANOVA test results showed that there were no significant differences $(p<0.05)$ between germination percentages according to the relative air humidity levels, sowing environment ${ }^{*}$ relative air humidity and pretreatment ${ }^{*}$ relative air humidity interactions. On the other hand, significant differences were found between germination percentages according to the pretreatments (Table 5).

\section{Soil moisture and germination percentage - Vlažnost tla i postotak klijavosti}

The highest germination percentages in the greenhouse were obtained as $34.7 \%$ at the $60.0-67.9 \%$ soil moisture level in the control trial, as $12.5 \%$ at the $44.0-51.9 \%$ soil moisture level in the stratification- 1 trial and as $15.5 \%$ at the $36.0-43.9 \%$ soil moisture level in the stratification- 2 trial. In the nursery, the highest germination percentages were obtained as $29.3 \%$ at the $36.0-43.9 \%$ soil moisture level in the control trial, as $26.5 \%$ at the $20.0-27.9 \%$ soil moisture level in the stratification- 1 trial and as $8 \%$ at the $60.0-67.9 \%$ soil moisture level in the stratification-2 trial.

No germinations were observed in the greenhouse until the soil moisture reached to the 36.0-43.9\% level in the control trial. However, germinations were observed in the greenhouse at the 20.0-27.9\% soil moisture level in the stratification-1 trial and at the $28.0-35.9 \%$ soil moisture level in the

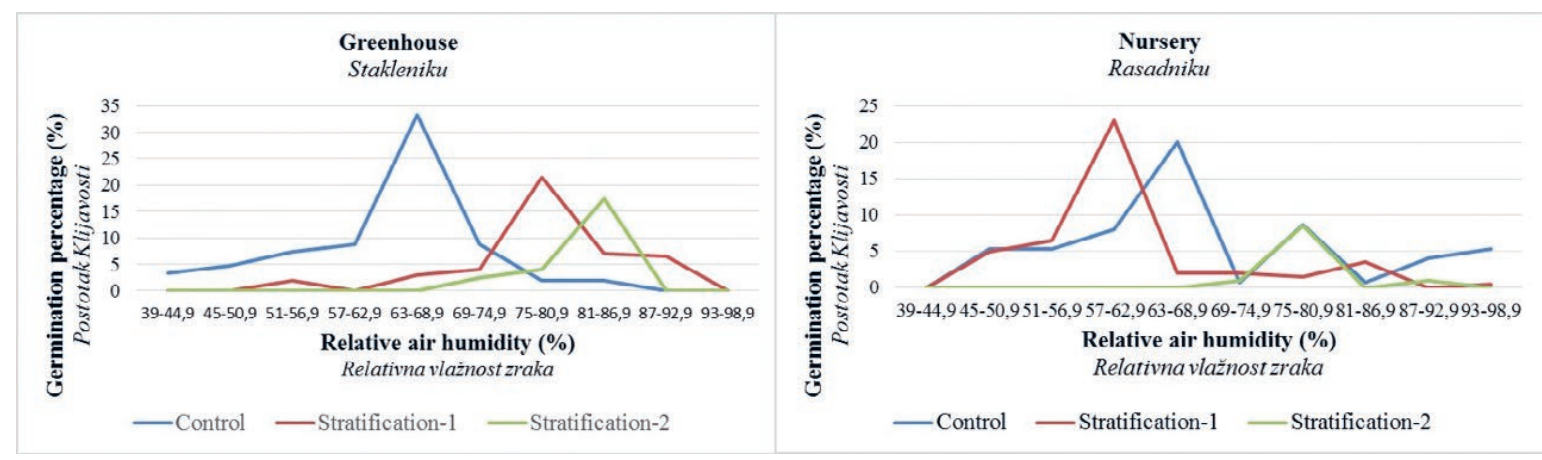

Figure 3. Germination percentages based on relative air humidity levels Slika 3. Postoci klijanja s obzirom na relativnu vlažnost zraka 
Table 6. Results of ANOVA on the basis of soil moisture

Tablica 6. Rezultati ANOVA za vlaga tla

$\begin{array}{lccccc}\begin{array}{l}\text { Variable Source } \\ \text { Izvor varijabilnosti }\end{array} & \begin{array}{c}\text { Sum of squares } \\ \text { Suma kvadrata }\end{array} & \begin{array}{c}\text { Degree of freedom } \\ \text { Stupnjevi slobode }\end{array} & \begin{array}{c}\text { Mean square } \\ \text { Srednji kvadrat }\end{array} & \begin{array}{c}\text { F-value } \\ \text { F-vrijednost }\end{array} & \begin{array}{c}\text { p-value } \\ \text { p-vrijednost }\end{array} \\ \begin{array}{l}\text { Sowing environment } \\ \text { Sjetveni Okoliš }\end{array} & 0,560 & 1 & 0,560 & 0,011 & 0,919 \\ \begin{array}{l}\text { Pretreatment } \\ \text { Predtretmani }\end{array} & 160,454 & 2 & 80,227 & 1,511 & 0,247 \\ \begin{array}{l}\text { Soil moisture level } \\ \text { Vlaga tla }\end{array} & 786,371 & 8 & 98,296 & 1,851 \\ \begin{array}{l}\text { Sowing environment * Soil moisture level } \\ \text { Sjetveni Okoliš * Vlaga tla }\end{array} & 355,098 & 8 & 44,387 & , 836 \\ \begin{array}{l}\text { Pretreatment * Soil moisture level } \\ \text { Predtretmani * Vlaga tla }\end{array} & 614,076 & 16 & 38,380 & 0,723 & 0,132 \\ \end{array}$

stratification-2 trial. Germinations were observed in the nursery at the $20.0-27.9 \%$ soil moisture level in the control and in the stratification-1 trials, but germinations were observed at $44.0-51.9 \%$ soil moisture level in the stratification-2 trial. While no germinations were observed in the greenhouse after the $60.0-67.9 \%$ soil moisture level in the stratification- 2 trial, germinations were observed after the $76.0-83.9 \%$ soil moisture level in the control trial and after the $84.0-91.9 \%$ soil moisture level in the stratification-1 trial. In the nursery no germinations were observed after the $60.0-67.9 \%$ soil moisture level in the stratification- 1 and in the stratification-2 trials, but germinations were observed at the 76.0-83.9\% soil moisture level in the control trial (Figure 4).

ANOVA test results showed that there were no significant differences $(p<0.05)$ between germination percentages according to the sowing environment, pretreatment, soil moisture levels, sowing environment* ${ }^{*}$ soil moisture level and pretreatment ${ }^{\star}$ soil moisture level interactions (Table 6).

\section{Mean germination time - Prosječno vrijeme klijanja}

While the average germination time was determined as 18 days in the control trial in the greenhouse, it was determined as 10 days in the stratification-1 trial and 9 days in the stratification-2 trial. In the nursery, the mean germination time was determined as 19 days in the control trial, as 25 days in the stratification- 1 trial and as 9 days in the stratification- 2 trial. It has been determined that the mean germination time in the greenhouse (12 days) was shorter than the mean germination time in the nursery (18 days). In addition, obtained results showed that stratification and sowing time have a positive effect on the mean germination time in the greenhouse.

\section{DISCUSSION AND CONCLUSIONS RASPRAVA I ZAKLJUČCI}

In the germination trials, higher average germination percentages were obtained in the greenhouse compared to the nursery after the control and stratification-2 process, while the average germination percentages obtained after the stratification-1 process were realized at the same rate in both greenhouse and nursery. In many studies in the literature, it is stated that higher germination percentages were obtained in the germination studies performed in maples and in some other species in the greenhouse compared to the germination trials carried out in the nursery (Göktürk et al. 2007; Özana 2019; Erdoğan Genç and Üçler 2020a; Erdoğan Genç and Üçler 2020b). Therefore, it is possible to state that the sudden environmental factor
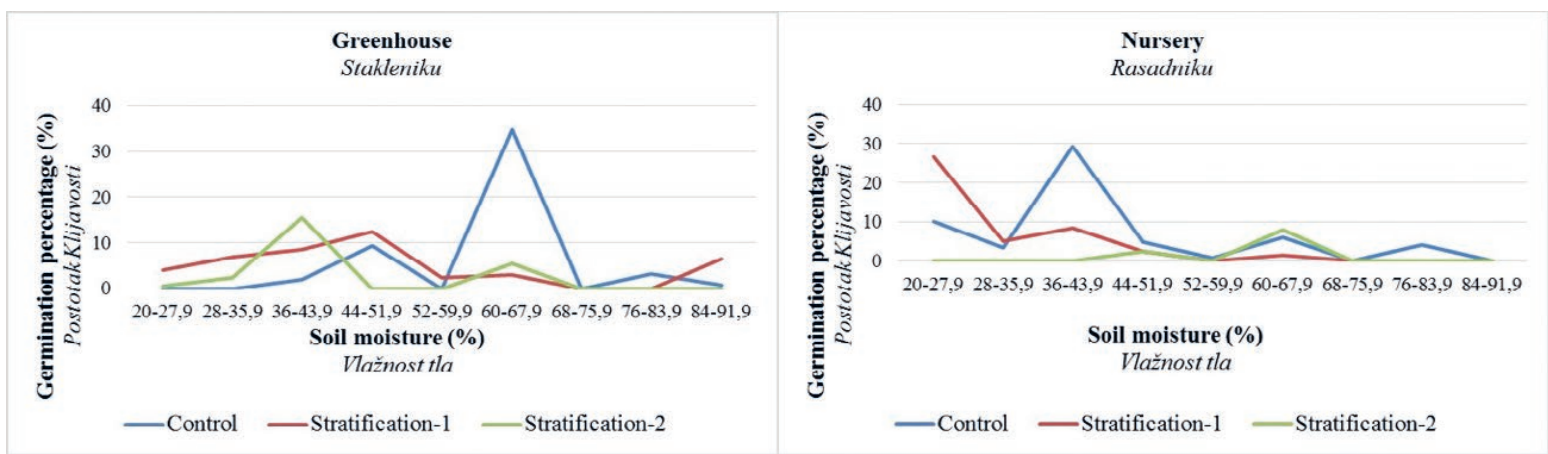

Figure 4. Germination percentages based on soil moisture levels Slika 4. Postoci klijanja s obzirom na vlažnost tla 
changes that occur during the germination process which affect the seed physiology are more controllable in the greenhouse environment.

At the same time, the highest germination percentages were determined in the control process both in the greenhouse and in the nursery. Therefore, the highest germination percentages were achieved in autumn sowings both in the greenhouse and in the nursery. In other words, the positive effect of the stratification process on the germination percentage was not revealed in this study. In many studies conducted on different species of maple, it is stated that the stratification process at varying times has a positive effect on the germination percentage (Tillberg and Pinfield 1982; Pinfield and Stutchbury 1990; Suzka et al. 1996; Evans and Blazich 1999; Yang and Lin 1999; Macdonald 2000; Phartyal et al. 2002; Erdoğan Genç and Üçler 2020a; Erdoğan Genç and Üçler 2020b). Stratification was continued until the first germinant appear in stratification medium. So, there should be no mistake about the applied stratification time. Although it has been stated in many studies on maple species that the stratification process has a positive effect on the germination percentage, obtaining the highest germination percentages in the seeds sown in the autumn without any pretreatment should be concluded that the sowing time, storage time and storage conditions were also extremely effective on the germination percentage in sycamore maple. In other words, it is possible to state that the sowing time, storage time and storage conditions might be caused changes in seed physiology. Hong and Ellis (1996) stated that the storage of seeds is related to properties such as seed shape, weight and moisture content in shedding period and those two important criteria such as seed moisture rate and 1000 seed weight at maturity stage play a determinant role in seed storage in maple species. Phartyal et al. (2003b) indicated that Himalayan maple seed desiccated to 5.91\% moisture content had a significant effect on the extension of viability compared to other moisture content levels irrespective of storage temperature. Therefore, $10 \pm 2 \%$ seed moisture content applied during storage in sycamore maple may have revealed unsuitable moisture content for seed viability during storage. In addition, Phartyal et al. (2003b) also indicated that interaction of seed moisture content, temperature and storage days showed that Himalayan maple seed stored at $-5{ }^{\circ} \mathrm{C}$ with $5.91 \%$ moisture content retained $28.0 \%$ viability up to 1275 days.

The best germination rate in the greenhouse environment was achieved at the $21.0-24.9^{\circ} \mathrm{C}$ air temperature level, 17.0$19.9^{\circ} \mathrm{C}$ soil temperature level, $63.0-68.9 \%$ relative air humidity level and $60.0-67.9 \%$ soil moisture level. The fact that germination percentages vary in both greenhouse and in nursery depending on air temperature, relative air humidity, soil temperature and soil moisture at different sowing times and obtaining a higher germination percentage in autumn sowing compared to spring and summer sowing can be evaluated as the effect of secondary dormancy in sycamore seeds.

In the study, it was observed that mean germination time was faster in the greenhouse in autumn and spring sowings, while the mean germination time in the greenhouse and in the nursery was equal in summer sowing. The highest mean germination time was obtained in summer sowing. It is also stated in different studies that higher mean germination time is achieved in sowings in the greenhouse compared to nursery and the increase in temperature generally increases the mean germination time (Göktürk et al. 2007; Yüksel 2011; Öztürk 2016).

Within the scope of the study, the best germination percentage was obtained in the control process and in the greenhouse environment. In addition, higher germination percentages were obtained in autumn sowing compared to spring and summer sowings. Germination percentage can be increased by performing controlled germination trials under constant temperature and humidity conditions in the greenhouse in autumn. It would be appropriate to choose the greenhouse environment without any pretreatment in the generative mass seedling propagation of sycamore maple. The study was carried out on a single seed family located outside the natural distribution area of the sycamore maple. Population-level studies in natural distribution areas may contribute with different scientific results.

\section{ACKNOWLEDGEMENTS ZAHVALA}

This study was carried for a MSc thesis at Karadeniz Technical University Institute of Science and Technology. Special thanks to Professor Sanda Tomičić Gitt for the Crotian translation.

\section{REFERENCES}

\section{LITERATURA}

- Baskin, C.C., Baskin, J.M., 1998: Seeds: Ecology, Biogeography and Evolution of Dormancy and Germination, Academic Press, New York, 1600p.

- Bell, S., 2009: Valuable broadleaved trees in the landscape: Valuable broadleaved forests in Europe (ed. by H Spiecker, S Hein, K Makkonen-Spiecker, M Thies) EFI Research-Report, European Forest Institute, Brill: Leiden, Boston, Köln, pp. 171-200.

- Beyhan, N., Marangoz, D., Demir, T., 1999: The effect of $\mathrm{GA}_{3}$ and stratification on hazelnut seed germination and seedlings grown with and without plastic tube. Ondokuzmayıs University, Journal of Faculty of Agriculture, 14 (3): 54-64.

- Binggeli, P., 1993: The conservation value of sycamore. The Quarterly Journal of Economics 87: 143-146.

- Bourgoin, A., Simpson, J.D., 2004: Soaking, moist-chilling and temperature effects on germination of Acerpensylvanicum seeds. Canadian Journal Forest Research, 34(10): 2181-2185. 
- Bradbeer, J.W., 1988: Seed Dormancy and Germination. Botany King's College London, Blackie Press, Newyork, USA, 151p.

- Bremer, L., Farley, K.A., 2010: Does plantation forestry restore biodiversity or creates green deserts: A synthesis of the effects of land-use transitions on plant species richness. Biodivers Conserv., 19: 3893-3915.

- De Castro, R.D., Hilhorst, H.W.M., 2004: Embebição Reativação Metabolismo. Pp. In: A.G. Ferreira and F. Borghetti (Eds.), Germinação: do básico ao aplicado, Porto Alegre, Artmed, pp.149162.

- Chen Shepley, S.C., Chang Judy, L.L., 1972: Does gibberellic acid stimulate seed germination via amylase synthesis? Plant Physiol., 49: 441-442.

- Derkx, M.P.M., 2000: Pretreatment at Controlled Seed MoistureContent as an Effective Means to Break Dormancy in Tree Seeds, In: Viemont, J.D. (Editor), Dormancy in Plants: From Whole Plant Behaviour to Cellular control, CABI Publishing, USA, p:65-69.

- Drâghici, C., Abrudan, I.V., 2010: Dormancy breaking of Acer and Fraxinus seeds-a brief review, Bulletin of Transilvania University of Braşov, 3 (52): 29-32.

- Erdoğan Genç, H., Üçler A.Ö., 2020a: Seed dormancy removal treatments and germination characteristics of Acer trautvetteri Medvedev seeds. Šumarski list, 9-10: 465-473.

- Erdoğan Genç, H., Üçler, A.Ö., 2020b: Effects of different treatments on seed dormancy breaking and germination in Acer cappadocicum Gleditsch var. cappadocicum. Šumarski list, 3-4: 159166.

- Evans, E., Blazich, F.A., 1999: Overcoming Seed Dormancy: Trees and Shrubs, Department of Horticulture Science, Horticulture Information Leaflets, NC State Universty, US (online) https://content.ces.ncsu.edu/overcoming-seed-dormancytreesand-shrubs (03.03.2021).

- Farhadi, M., Tigabu, M., Arian, A.G., Sharifani, M., Daneshvar, A., Oden, O.C., 2013: Pre-sowing treatment for breaking dormancy in Acer velutinum Boiss. seed lots. Journal of Forestry Research, 24 (2): 273-278.

- Farmer, R.E., Cunningham, M., 1981: seed dormancy of red maple in east Tennesee, Society of American Foresters, Forest Science, 27 (3): 446-448.

- Gleiser, G., Carmen Picher, M., Veintimilla, P., Martinez, J., Verdú, M., 2004: Seed dormancy in relation to seed storage behaviour in Acer. Botanical Journal of the Linnean Society, 145: 203-208.

- Göktürk, A., Ölmez, Z., Temel, F., Yahyaoğlu, Z., 2007: Effects of some pre-treatments on germination of Russian olive (Elaeagnus angustifolia L.) seeds. Journal of Süleyman Demirel University Faculty of Forestry, A (2): 32-41.

- Gültekin, H.C., 2007: Maple (Acer L.) species and seedling propagation tecniques. Republic of Turkey, Ministry of Agriculture and Forestry, General Directorate of Combating Desertification and Erosion, Ankara, 24p (In Turkish).

- Hein, S., 2009: Distribution of valuable broadleaved forests in Europe, Appendix B: Valuable broadleaved forests in Europe (ed. by H Spiecker, S Hein, K Makkonen-Spiecker \& M Thies) EFI Research-Report, European Forest Institute, pp. 251-256.

- Hein, S., Collet, C., Ammer, C., Le Goff, N., Skovsgaard, J.P., Savill, P., 2009: A review of growth and stand dynamics of Acer pseudoplatanus L. in Europe: Implications for silviculture. Forestry, 82 (4): 361-385.
- Heitz, R. and Rehfuess, K.E. 1999: Reconversion of Norway spruce (Picea abies (L.) Karst.) stands into mixed forests: effects on soil properties and nutrient fluxes. In: Olsthoorn, A.F.M, Bartelink, H.H., Gardiner, J.J., Pretzsch, H., Hekhuis, H.J., Franc, A. (Eds.): Management of mixed-species forest: silviculture and economics. IBN Scientific Contributions, pp. 46-57.

- Heydecker, W., 1977: Stress and seed germination: An agronomic view. In: Elsevier, A.K., Ed., The Physiology and Biochemistry of Seed Dormancy and Germination, North Holland and Biomedical Press, Amsterdam, pp. 237-282.

- Hong, TD., Ellis, RH., 1996: Ex situ Biodiversity Conservation by Seed Storage: Multiple-Criteria to Estimate Seed Storage Behavior. Seed Science and Tecnology, 25: 157-161.

- ISTA, 1996: International Rules for seed Testing, International Seed Testing Association (ISTA), Seed Science and Technology, Forest Service, US.

- Kölling, C., 2007: Klimahüllen für 27 Waldbaumarten. Allgemeine Forstzeitschrift/Der Wald, 23: 1242-1245.

- Kumar, S., Shamet, G.S., Gupta, D., Kumari, N., Kumar, R., 2017: Effect of Stratification and Gibberellic Acid on Germination and Seedling Growth of Acer acuminatum in North Western Himalayas, Indian Forester,143 (11): 1105-1111.

- Jones, E.W., 1945: Biological flora of the British Isles, Acer L. Journal of Ecology, 32: 215-252.

- Macdonald, B., 2000: Practical Woody Plant Propagation for Nursery Growers. Volume I, Timber Press, Portland, Oregon, USA, 684p.

- Özana, Y., 2019: The effects of some treatments on germination of Tilia tomentosa and Tilia rubra subsp. caucasica seeds. Master Science Dissertation, Artvin Çoruh University Institute of Science and Technology, Artvin, 34p.

- Öztürk, C., 2016: The study of some pretpeatments which effect the germination of laurel seeds (Laurus nobilis L.). Master Science Dissertation, Artvin Çoruh University Institute of Science and Technology, Artvin, 43p.

- Phartyal, S.S., Thapliyal, R.C., Koedam, N., Sandrine, G., 2002: Ex situ conservation of rare and valuble forest tree species through seed-gene bank. Current science, 83 (11): 1351-1357.

- Phartyal, S.S., Thapliyal, R.C., Nayal, J.S., Joshi, G., 2003a: Seed dormancy in Himalayan maple (Acer caesium): Effect of stratification and phyto-hormones. Seed Science and Technology, 31: $1-11$.

- Phartyal, S.S., Thapliyal, R.C., Nayal, J.S., Joshi, G., 2003b: Storage of Himalayan maple (Acer caesium) seed: A threatened tree species of the Central Himalayas. Seed Science and Technology, 31: 149-159.

- Pinfield, N.J., Stutchbury, P.A., 1990: Seed dormancy in Acer: The role of testa-imposed and embriyo dormancy in Acer velutinum. Annals of Botany, 66 (2): 133-137.

- Piotto, B., Bartolini, G., Bussotti, F., Calderón García, A.A., Chessa, I., Ciccarese, C., Ciccarese, L., Crosti, R., Cullum, F.J., Di Noi, A., García-Fayos, P., Lambardi, M., Lisci, M., Lucci, S., Melini, S., Reinoso, J.C.M., Murranca, S., Nieddu, G., Pacini, E., Pagni, G., Patumi, M., García, F.P., Piccini, C., Tranne, M.R.G., 2001: Fact sheets on the propagation of mediterranean trees and shrubs from seed. Chapter 12, In: Seed propagation of mediterranean trees and shrubs (Beti Piotto and Anna Di Noi Editors), ADAPT- Agency for the Protection of the Environment and for Technical Services, Roma, Italy, pp.110-167.

- Pommerening, A., 1997: Erwartete und beobachtete Artendurchmischung am Beispiel von Buchen-Edellaubholzbeständen. 
Sektion Ertragskunde im Deutschen Verband Forstlicher Forschungsanstalten, Jahrestagung 1997, Grünberg, 12.-14. Mai 1997, pp. 45-59.

- Savage, W.E., Bergervoet, J.H.V., Bino, R.J., Clay, H.A., Groot, S.P.C., 1998: Nuclear replication activity during seed devolepment, dormancy breakage and germination in three species: Norway maple (Acer platanoides L.), Sycamore (Acer pseudoplatanus L.) and Cherry (Prunus avium L.). Horticulture Research International, Annnals of Botany, 81: 519-526.

- Spiecker, H., Hein, S., Makkonen-Spiecker, K., Thies, M., 2009: Valuable broadleaved forests in Europe. EFI Research-Report 22. European Forest Institute, Brill, Leiden, Boston, Köln, 256p.

- SPSS, 2011: IBM Corp. Released 2011. IBM SPSS Statistics for Windows, Version 20.0. Armonk, NY: IBM Corp.

- Stejskalová, I., Kupka, I., Miltner, S., 2015: Effect of gibberellic acid on germination capacity and emergence rate of sycamore maple (Acer pseudoplatanus L.) seeds. Journal of Forest Science, 61, 205 (8): 325-331,

- Suszka B., Muller, C., Bonnet Masimbert, M., 1996. Seeds of Forest Broadleaves: from Harvest to Sowing. INRA Editions, France, 294p.

- Thies, M., Hein, S., Spiecker, H. 2009: Results of a questionnaire on management of valuable broadleaved forests in Europe: Valuable broadleaved forests in Europe (ed. by H Spiecker, S Hein, $\mathrm{K}$ Makkonen-Spiecker \& M Thies) EFI Research-Report, European Forest Institute, pp. 27-42.

- Tillberg, E., Pinfield, N.J., 1982: Changes in abscisic acid levels during after-ripening and germination of Acer platanoides L. seeds. New. Phytol., 92: 167-172.

- Tremblay, M.F., Mauffette, Y., Bergeron, Y., 1996: Germination eesponses of nothern red maple (Acer rubrum) populations. Forest Science, 42 (2): 154-159.
- Tylkowski, T., 1995: Adaptation of dormant seeds to sowing by cyclically repeated soaking in water, III. Sycamore maple, Acer pseudoplatanus L. Sylwan, 139 (7): 15-23.

- Ürgenc, S., 1998: Ağaçlandırma Tekniği (Afforestation Techniques). İstanbul University Publication No: 3994/441, İstanbul, 600p (In Turkish).

- Vacek, S., Vacek, Z, Kalousková, I., Cukor, J., Bílek, L., Keith Moser, W., Bulušek, D., Podrázský, V., Řeháček D., 2018: Sycamore maple (Acer pseudoplatanus L.) stands on former agricultural land in the Sudetes - evaluation of ecological value and production potential. Dendrobiology, 79: 61-76.

- Weber, G., Rehfuess, K.E., Kruetzer, K., 1993: Über den Einfluß naturnaher Waldwirtschaft auf den chemischen Bodenzustand. Allgemeine Forst Zeitschrift, 48: 68-71.

- Yaltırık, F., 1971: The taxonomical study on the macro and micro morphological characteristics of indigenous maples (Acer L.) in Turkey. İstanbul University. Publication No:1661/179, İstanbul, 232p (In Turkish).

- Yang J.C., Lin, T.P., 1999: Seed Storage Behavior of Five Species of Acer, Taiwan Journal of Forest Science, 14 (4): 479-492.

- Young, J.A., Young, C.G., 1992: Seeds of Woody Plants in North America: Revised and Enlarged Edition, Dioscorides Press, Portland, Oregon, pp.124-126.

- Yüksel, T., 2011: Researches on the seed characteristics of Taurus fir (Abies cilicica Carr.), Master Science Dissertation, Kahramanmaraş Sütçü İmam University Institute of Science and Technology, Kahramanmaraş, 59p.

- Zasada, J.C., Strong, T.F., 2008: Aceraceae-Maple family Acer L. Maple. Woody Plant Seed Manual. United States Department of Agriculture, Forest Service, Agriculture Handbook 727 (Edt: Franklin T. Bonner and Robert P. Karrfalt), pp. 204-216.

\section{SAŽETAK}

Istraživan je utjecaj zaštićenog prostora (staklenik) i rasadnik, predsjetvene pripreme sjemena (hladnovlažna stratifikacija), različitog godišnjeg doba sjetve (jesen, proljeće i ljeto) i nekih klimatskih čimbenika (temperatura zraka, relativna vlažnost zraka, temperatura tla i vlaga tla) na klijavost sjemena Acer pseudoplatanus L. Sjeme je sakupljeno sa stabala u kampusu Tehničkog sveučilišta Karadeniz. Provedena su tri različita ispitivanja klijanja; (1) izravna sjetva u jesen nakon sakupljanja sjemena (Kontrola), (2) sjetva stratificiranog sjemena u proljeće (Stratifikacija-1) i (3) sjetva stratificiranog sjemena ljeti (Stratifikacija-2). Tijekom procesa klijanja povremeno su mjerene temperatura zraka, relativna vlažnost zraka, temperatura tla i vlaga tla. Na taj način su utvrđene promjene u postotku klijavosti u različitim sjetvenim okruženjima pod utjecajem određenih klimatskih čimbenika. Viši postotci klijavosti zabilježeni su u slučaju jesenske sjetve (Kontrola) u usporedbi s proljetnom (Stratifikacija-1) i ljetnom sjetvom (Stratifikacija-2). Najveći postotak klijavosti utvrđen je u kontrolnim ispitivanjima (70\% u stakleniku i 58\% u rasadniku). Prikupljeni rezultati klijavosti tijekom različitog perioda sjetve otkrili su sekundarno mirovanje kod sjemena Acer pseudoplatanus L. Utvrđeno je da je srednje vrijeme klijanja u stakleniku (12 dana) bilo kraće od prosječnog vremena klijanja u rasadniku (18 dana). Osim toga, dobiveni rezultati pokazali su da stratifikacija i vrijeme sjetve pozitivno utječu na srednje vrijeme klijanja u stakleniku. Održavanje nekih klimatskih čimbenika konstantnima (temperatura zraka $21.0-24.9^{\circ} \mathrm{C}$; temperatura tla $19.0-19.9^{\circ} \mathrm{C}$; relativna vlažnost zraka 63.0-68.9\%; vlažnost tla 60.0-67.9\%) tijekom vegetativnog razmnožavanja u stakleniku bi trebalo utjecati na masovnu proizvodnju sadnica u Acer pseudoplatanus L., a u svrhu postizanja najboljih rezultata klijavosti.

KLJUČNE RIJEČI: Hladno-vlažna stratifikacija; godišnje doba sjetve; skladištenje sjemena; staklenik; rasadnik 